Brit. J. industr. Med., 1950, 7, 1-11.

\title{
SKIN CANCER IN THE ENGINEERING INDUSTRY FROM THE USE OF MINERAL OIL
}

\author{
BY \\ C. N. D. CRUICKSHANK and J. R. SQUIRE \\ From the Medical Research Council Industrial Medicine Research Unit, Birmingham Accident Hospital, \\ and Department of Pathological Studies, University of Birmingham
}

(RECEIVED FOR PUBLICATION NOVEMBER 28, 1949)

\section{Introduction}

Although the ætiological association between soot and cancer of the scrotum was recognized by Percival Pott as early as 1775 , the role of mineral oils in the production of skin cancer was not recognized until considerably later. Joseph Bell of the Edinburgh Royal Infirmary reported a case of carcinoma of the scrotum in a Scottish shale oil worker in 1876. Southam and Wilson (1922) pointed out the high incidence of scrotal cancer in Lancashire cotton mule spinners and, although various theories of causation were advanced, the production of tumours in mice by the cutaneous application of lubricating oil by Leitch (1924) indicated that some constituent of the spindle oil was the carcinogen. The carcinogenicity of a large number of petroleum oils was investigated by Twort and Twort (1931) who showed that many were carcinogenic.

The high incidence of skin cancer. in Scottish shale oil workers was described by Scott (1922). Experimental tumours were produced in mice by applying shale oil to the skin (Leitch, 1922), and finally Berenblum and Schoental (1943), by using the chromatographic method of separation, isolated 3.4 benzpyrene from this oil and showed that there were other carcinogens present. The carcinogenic agents in petroleum oils, however, probably differ qualitatively and quantitatively from those in shale oils which are produced by destructive distillation. So far no pure carcinogens have been isolated from petroleum oils.

In 1920, it was made obligatory to notify occupational skin cancer due to paraffin or mineral oil or any of their compounds, residues or products, contracted in a factory or workshop. These notifications have been invaluable for finding out the extent to which the disease occurs, and in conjunction with the examination of death certificates, have furnished the basis of the extensive researches of S. A. Henry (1946; 1947). This work has emphasized the high incidence of skin cancer in cotton operatives, but in the engineering industry relatively few cases have been observed. For example, in the period 1911-38, only 71 metal workers (including precious metals) died with scrotal cancer out of a total of 715 such deaths recorded among workers exposed to mineral oil, the bulk of the cases having occurred in the cotton industry. The incidence in the engineering industry appears even lower when notifications instead of deaths are considered, but, as is generally recognized, notifications are unreliable until a definite hazard is widely appreciated. Our studies indicate that the hazard of skin cancer is to be found in certain jobs in the engineering industry. The evidence is drawn from three sources : (a) the observation of workers who are exposed to cutting oils in the " bar automatic" machine shops of local light engineering firms; (b) an analysis of the records of patients reporting with scrotal cancer to the Birmingham United Hospital during the period $1939-48$; (c) the production of tumours in animals by painting with a sample of the cutting oil in current use in automatic machines.

\section{Field Examination of Workers Exposed to Cutting Oils}

Environment.-Mineral oils are used in a wide variety of engineering processes, e.g., as lubricants, as coolants in metal-cutting operations, as quenching agents in metal-hardening, etc. The most continuous and widespread skin contamination of workmen is usually to be seen in 'bar automatic' shops, where groups of 20-150 workmen may be all exposed under similar conditions. The automatic machine tool is designed to conduct a series of operations without removal of the work, e.g., upon a long metal bar turning out some such object as a bolt. These machines frequently work at high speed requiring large amounts of coolant upon the tool edges, and, 
as they are at present designed, much oil is ejected into the shop.

The cutting oils in use today are usually blended by admixing a smaller amount (usually about 10 per cent.) of ' cutting compound' with a petroleum oil distillate of the lubricant grade. In ge:eral, the basic lubricant fraction is said to be not very dissimilar from the 'spindle oil' used in the cotton industry, though it may be somewhat 'heavier', i.e. a distillate 'cut' of higher boiling point. The ' cutting compounds' are made by a large number of specialist manufacturers, and their precise chemical compositions are difficult to define, being also in many instances trade secrets. Usually, they are made by 'chlorinating' or 'sulphurizing" reactive oils, some of vegetable origin, and others occasionally in recent years derived from highly aromatic ' extracts' from petroleum oil distillates.

The machine tools are generally arranged in banks with a common oil supply. The oil circulates from a reservoir through the machines and is collected in a sump. From here it passes through a purification plant which removes the swarf (fine metal filings and shavings) and at this stage it is sterilized by passage over an electrically heated coil. The oil is then pumped back into the reservoir. As oil is lost in the machines, this reservoir has to be replenished. The extent of the oil loss is considerable and inspection of the machines at work reveals how this occurs. A certain small proportion is oxidized, as shown by the smoke which can sometimes be seen arising from the cutting edge of the tool, but a much larger quantity is thrown into the air as a fine spray which eventually settles on machines and floor to form a film. Not only is the operator exposed to this spray, but also in the course of his work he often has to adjust the tool and the metal while the machine is in motion. In spite of the splash guards which are at present in use, gross skin contamination is usual. Since the machine operator's clothing soon becomes soaked through with oil, the skin on the thighs and genital regions as well as on the arms becomes very oily. A leather apron may be worn but its use is not compulsory. Shirt sleeves are often cut off short above the elbow, since the friction from rolled up sleeves is found to rub oil into the skin. Nevertheless, it is the rule to see men mopping down their arms with cotton waste to remove excessive quantities of oil. In general, the degree of skin contamination with oil in bar automatic machine shops is very much greater than that to be seen in mule-rooms in the cotton industry.

Skin Lesions on the Arms of Operators. - Examinations were carried out of the hands and forearms of the workers in the machine shops of three separate factories. As a complete skin examination of every worker would have interfered with production, only the hands and forearms of the majority of the workers were examined; but as these parts sustain the greatest exposure to cutting oil, their inspection gives a reliable index of the occurrence of a skin hazard. Moreover, a sample of the population was subjected to a complete skin examination, and it was found that where other regions, e.g. thighs or knees, were involved, the hands and forearms were affected also, although sometimes to a lesser extent. During the examination, the men were questioned regarding their ages and the duration of their exposure to cutting oil.

A total of 138 employees was examined, representing the complete day shift in two factories and the complete day and night shifts in a third. The lesions found on the arms of these workers in the separate factories were almost identical in nature and incidence, and consequently any local effects due to the method of working, washing facilities, etc. in any one factory may be excluded. For convenience, the findings in all three factories will be discussed together.

Oil Folliculitis.-The triad of lesions, comedones, folliculitis and follicular scars constituting the syndrome of oil folliculitis was the characteristic finding (Plate I.) The areas most affected by oil folliculitis were those with the greatest exposure, e.g. the extensor surfaces of the forearms, knees and thighs. The factor of friction rubbing the oil into the skin appeared to be of considerable importance. Thus one worker, who had the habit of rubbing his arms against the hips in an attempt to wipe off the oil, had severe folliculitis of the volar surfaces of the arms. Moreover those workers who wore their sleeves fastened at the wrist had the most severe folliculitis in those parts rubbed by the cuffs, while those who worked with their sleeves rolled up developed folliculitis of the elbows.

The overall incidence of oil folliculitis (excluding those workers who had only comedones and scars) was 79.6 per cent. (110 cases). Comparison of the incidence of folliculitis in groups exposed for various periods showed that the onset of the condition was early, and that after the first year the incidence was constantly in the region of 80 per cent. of exposed personnel, there being no evidence of 'immunity' or 'hardening' in the more experienced workers.

In only three instances was the oil folliculitis severe and the workers themselves did not appear unduly perturbed. A few of the younger workers, however, objected to the unsightly blemishes.

Hyperkeratoses.-In addition to inflammatory lesions of the hair follicles, two kinds of hyper- 


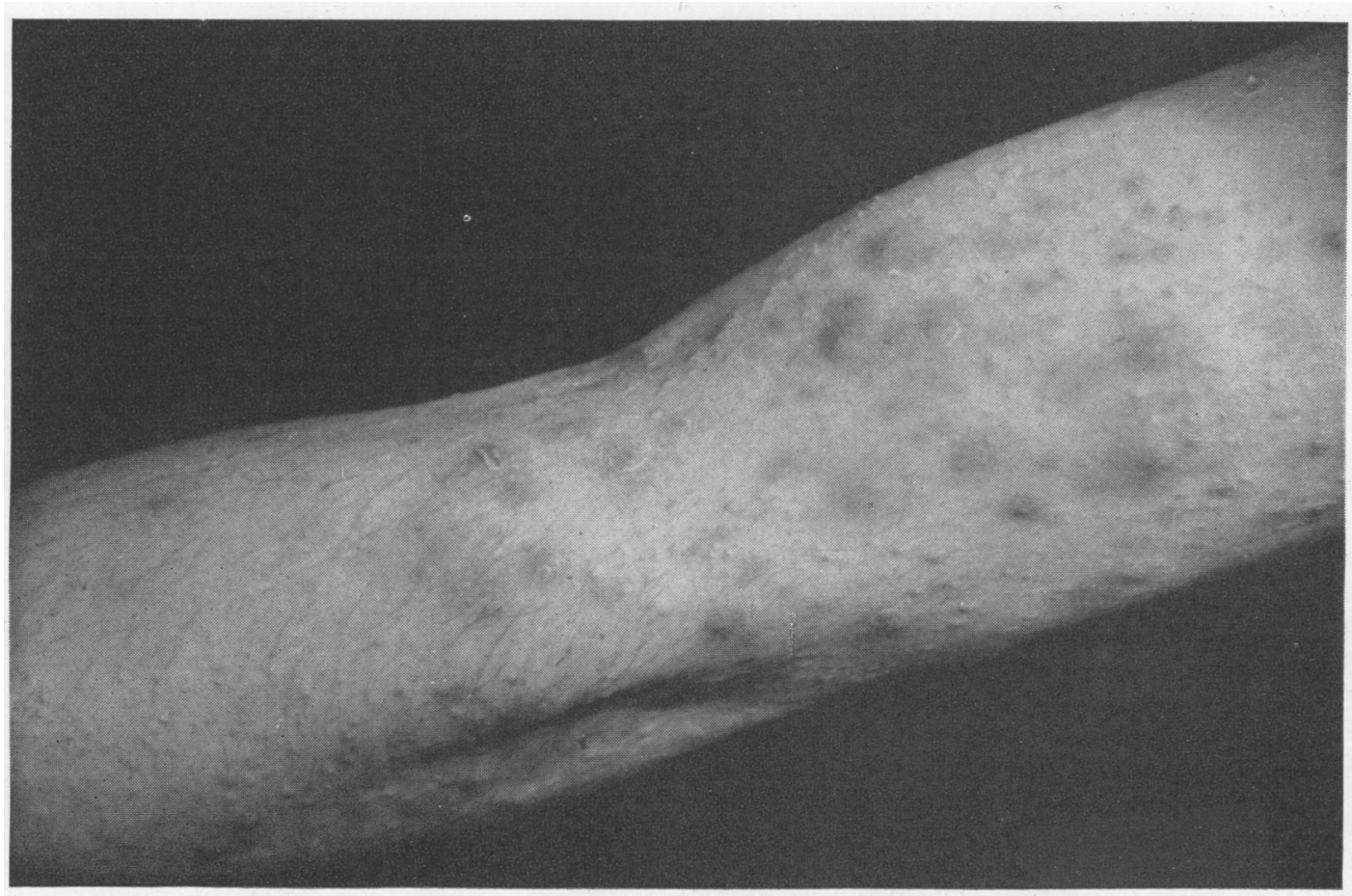

PLATE I.-Severe Oil Folliculitis-showing comedones, folliculitis and granulomatous lesions.

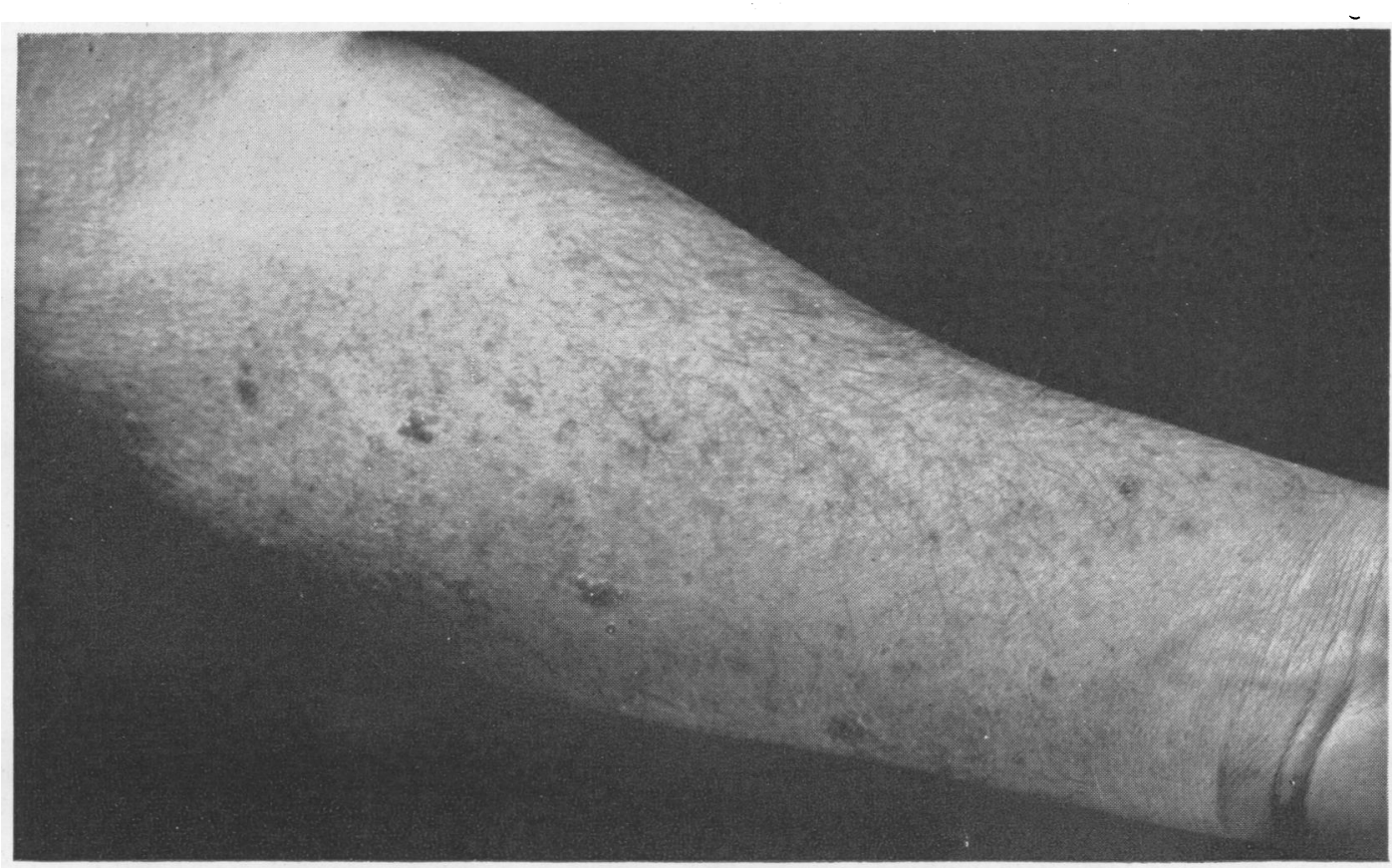

Plate II.-Hyperkeratotic lesions on arms of machine operator. This patient eventually died as the result of scrotal cancer. 
keratotic growths were found on the arms of some of the workers : (1) flat, white, circular, hyperkeratotic areas, 1-2 $\mathrm{mm}$. in diameter, in the form of smooth plaques. These plaques were only slightly raised above the surrounding skin, and were frequently grouped in small clusters; (2) rugose, pigmented warts, generally round or oval, irregular, and considerably raised above the surrounding skin (Plate II). Occasionally, both types of hyperkeratotic growth were present. In three instances, pigmented atrophic pre-cancerous skin (shark skin, shagreen skin) was noted. The two types of wart were similar to those present on the arms of tar workers, and of mule spinners who have been exposed for long periods to spindle oil.

Among the 138 workers examined, warts were noted in 45 (33 per cent.). In Table I are set out the findings showing the relationship between the duration of exposure in automatic shops and the presence of hyperkeratoses or warts. As will be seen, the percentage of men affected rises steadily with exposure, over 50 per cent. of workers with more than 15 years' exposure showing these changes.

In factories $B$ and $C$, each man was questioned about his occupation (if any) before entering the automatic shop. None had been exposed to tar or pitch, but a few of the men had previously worked with oils or suds in other jobs. It is possible that this exposure accounts in some instances for the hyperkeratoses noted in the men with less than 5 years' exposure.

Naturally, most of the men with long periods of exposure fell into the older age groups. In Table II, this is taken into account by showing the men grouped by age as well as by duration of exposure. Inspection of the 15 to 30 and 31 to 40 -year-old men suggests that exposure time is the major determining factor in the development of warts.

Statistical testing using $\chi^{2}$ was employed to consider separately the effect on the incidence of hyperkeratoses attributable to : $(a)$ variation in age with similar periods of exposure; (b) different periods of exposure in groups with similar ages.

In the cases studied, the age differences did not affect significantly the incidence of hyperkeratoses. This having been established, the age groups were pooled as in the totals shown at the foot of Table II, i.e. $5 / 54$ for $0-5$ years' exposure, $10 / 28$ for $6-10$ years, $7 / 18$ for $11-15$ years, and $23 / 38$ for 15 or more years' exposure time. $\chi^{2}$ testing gives a value of 27.33 , which for the 3 degrees of freedom involved implies that these results would have occurred less than 1 in 1,000 occasions by chance alone. Almost certainly, therefore, the hyperkeratoses found are to be attributed to occupational exposure in the automatic shops.
TABLE I

INCIDENCE OF HYPERKERATOSES IN AUTOMATIC MACHINE OPERATORS

\begin{tabular}{|c|c|c|c|}
\hline $\begin{array}{l}\text { Duration of Oil } \\
\text { Exposure in } \\
\text { automatic shops } \\
\text { (years) }\end{array}$ & Factory & $\begin{array}{l}\text { No. in } \\
\text { group }\end{array}$ & $\begin{array}{l}\text { Hyperkeratoses } \\
\text { or warts }\end{array}$ \\
\hline $0-1$ & $\begin{array}{l}\mathbf{A} \\
\mathbf{B} \\
\mathbf{C}\end{array}$ & $\left.\begin{array}{r}13 \\
9 \\
3\end{array}\right\} 25$ & $\left.\begin{array}{l}0 \\
1 \\
0\end{array}\right\} 1(4 \%)$ \\
\hline $2-5$ & $\begin{array}{l}\mathbf{A} \\
\mathbf{B} \\
\mathbf{C}\end{array}$ & $\left.\begin{array}{r}13 \\
2\end{array}\right\} 29$ & $\left.\begin{array}{l}0 \\
4 \\
0\end{array}\right\} 4(13 \cdot 8 \%)$ \\
\hline $6-10$ & $\begin{array}{l}\mathbf{A} \\
\mathbf{B} \\
\mathbf{C}\end{array}$ & $\left.\begin{array}{r}12 \\
14 \\
2\end{array}\right\} 28$ & $\left.\begin{array}{l}3 \\
6 \\
1\end{array}\right\} 10(35 \cdot 7 \%)$ \\
\hline $11-15$ & $\begin{array}{l}\mathbf{A} \\
\mathbf{B} \\
\mathbf{C}\end{array}$ & $\left.\begin{array}{l}9 \\
6 \\
3\end{array}\right\} 18$ & $\left.\begin{array}{l}1 \\
5 \\
1\end{array}\right\} 7(38 \cdot 8 \%)$ \\
\hline $16-20$ & $\begin{array}{l}\mathbf{A} \\
\mathbf{B} \\
\mathbf{C}\end{array}$ & $\left.\begin{array}{r}14 \\
9 \\
1\end{array}\right\} 24$ & $\left.\begin{array}{l}5 \\
7 \\
1\end{array}\right\} 13(54 \cdot 2 \%)$ \\
\hline 21 & $\begin{array}{l}\mathbf{A} \\
\mathbf{B} \\
\mathbf{C}\end{array}$ & $\left.\begin{array}{l}8 \\
5 \\
1\end{array}\right\} 14$ & $\left.\begin{array}{l}4 \\
5 \\
1\end{array}\right\} 10(71 \cdot 4 \%)$ \\
\hline All groups & $\underset{\text { C, B, }}{\text { and }}$ & 138 & $45(32 \cdot 6 \%)$ \\
\hline
\end{tabular}

Comments.-Since hyperkeratoses are found among workers exposed to known carcinogenic agents, these results may be regarded as a serious warning sign. The widespread occurrence of folliculitis on the other hand is evidence, if that were needed, that heavy contamination with oil on the forearms is the rule in automatic shops, and that this oil usually persists after the end of the day's work. That oil contamination of thighs and genitals is also common can be seen from superficial inspection of clothing and examination of selected workers.

\section{A Case of Scrotal Carcinoma}

Further evidence for the possible carcinogenicity of cutting oils was provided by the occurrence of a scrotal carcinoma in an operator from one of the machine shops inspected.

The patient, a male aged 42 , had been exposed to various cutting oils for 21 years in the automatic machine shop in Factory A. He had had no exposure to other carcinogenic agents. He first noticed a growth on the scrotum in November 1946 and stated that it increased rapidly in size. He did not report it until December 1946 when it was removed at operation. The left 
TABLE II

RELATIONSHIP OF AGE AND DURATION OF OIL EXPOSURE TO DEVELOPMENT OF HYPERKERATOSES IN MACHINE OPERATORS

\begin{tabular}{|c|c|c|c|c|c|}
\hline \multirow{2}{*}{$\begin{array}{c}\text { Age } \\
\text { (years) }\end{array}$} & \multicolumn{5}{|c|}{$\begin{array}{l}\text { Exposure time } \\
\text { (years) }\end{array}$} \\
\hline & $0-5$ & $6-10$ & $11-15$ & $15+$ & All groups \\
\hline $15-30$ & $\frac{0}{20} \quad(0 \%)$ & $\begin{array}{ll}2 & (22 \%) \\
\overline{9} & \end{array}$ & $\begin{array}{l}1(25 \%) \\
\frac{4}{4}\end{array}$ & $\begin{array}{l}2(100 \%) \\
\overline{2}\end{array}$ & $\frac{5}{35}(14 \%)$ \\
\hline $31-40$ & $\frac{1}{27} \quad\left(4_{\%}^{\circ}\right)$ & $\frac{6}{16}(37 \%)$ & $\frac{6}{11}(55 \%)$ & $\begin{array}{ll}5 & (56 \%) \\
9 & \end{array}$ & $\frac{18}{63}(29 \%)$ \\
\hline $41-50$ & $\begin{array}{l}4(100 \%) \\
\frac{4}{4}\end{array}$ & $\begin{array}{ll}0 & - \\
\overline{0} & \end{array}$ & $\begin{array}{ll}0 & (0 \%) \\
-1 & \end{array}$ & $\frac{7}{12} \quad(58 \%)$ & $\frac{11}{17}(65 \%)$ \\
\hline $50+$ & $\begin{array}{ll}0 & (0 \%) \\
\overline{3} & \end{array}$ & $\begin{array}{l}2(67 \%) \\
\overline{3}\end{array}$ & $\begin{array}{ll}0 & (0 \%) \\
\overline{2} & \end{array}$ & $\frac{9}{15} \quad(60 \%)$ & $\frac{11}{23}(48 \%)$ \\
\hline All & $\begin{array}{c}\frac{5}{54} \\
\frac{5}{54}\end{array}$ & $\frac{10}{28}(36 \%)$ & $\frac{7}{18}(39 \%)$ & $\frac{23}{38} \quad(61 \%)$ & $\frac{45}{138}(33 \%)$ \\
\hline
\end{tabular}

Numerator $=$ number of men with hyperkeratoses.

Denominator $=$ number of men examined.

testicle and the left half of the scrotum were removed, the right inguinal lymph glands were dissected and he subsequently had deep $x$-ray therapy to the left inguinal lymph glands.

Subsequent Course.-In May 1947 the incisions had healed, but in the left groin there was an area of $2 \mathrm{in} . \times \frac{1}{2}$ in. of granulation tissue surrounded by marked scarring. The subcutaneous tissues in this region were hard and firm and there was some obstruction of the lymph drainage of the left leg. Examination of his arms showed multiple hyperkeratotic growths (Plate II) many of them of the pigmented type, and there were in addition numerous small pitted scars-evidence of old oil folliculitisand areas of atrophic skin ("shark skin" of Prosser White). Most of the hair follicles on the thighs and arms showed widely dilated mouths. There was no evidence of active folliculitis, as he had not been exposed to oil for the past 6 months.

The patient returned to light sedentary work for a period of six months, but his general condition gradually deteriorated. He developed in the left groin large ulcerating secondary growths which gave rise to repeated hæmorrhages and to œdema of the foot. He eventually died of broncho-pneumonia.

\section{Scrotal Cancer in the Birmingham Area}

If there is an appreciable risk of industrial skin cancer in the engineering industry, it would be expected that cases should occur in Birmingham, since it is one of the largest centres of light engineering in the country. Accordingly, a study was made of the patients treated for scrotal cancer at the United Birmingham Hospitals (the teaching hospi- tals of the city) during the past 10 years. The investigation was confined to scrotal cancer since : (a) the incidence of scrotal cancer in men not exposed to occupational carcinogens is exceedingly low ; $(b)$ in about half of the cases of skin cancer reported among workers exposed to carcinogenic oils (e.g. cotton operatives) the scrotal skin is affected (Henry, 1947).

Method.-The basic data were obtained from the follow-up records and histological reports of the Queen Elizabeth and General Hospitals, Birmingham. Where the diagnosis of scrotal carcinoma had been made, the case-notes were examined, the patients interviewed and examined if possible, and the diagnosis checked by reference to the original histological sections. Only definite examples of squamous cell carcinoma (epithelioma) were included in the series. Enquiries addressed to the pathological departments of the other large hospitals in the city dealing with surgical patients led to the conclusion that few, if any, records of patients with this condition were to be found.

Findings. - Thirty-four patients with scrotal cancer attending during the years 1939-48 were traced. Twenty-eight of these resided in the Greater Birmingham area, five of the remainder in the neighbouring towns of Wolverhampton, Dudley, Nuneaton, Rugby, and Coventry. The relevant findings are set out in Table III (overleaf), the 
TABLE III

ANALYSIS OF 34 PATIENTS WITH SCROTAL CANCER ATTENDING UNITED BIRMINGHAM HOSPITALS, $1939-48$

\begin{tabular}{|c|c|c|c|c|c|c|c|c|c|}
\hline \multirow{3}{*}{$\begin{array}{c}\text { Year } \\
\text { report- } \\
\text { ing }\end{array}$} & \multicolumn{9}{|c|}{ Main Exposure } \\
\hline & \multicolumn{3}{|c|}{ Oil } & \multicolumn{3}{|c|}{ Pitch, etc. } & \multicolumn{3}{|c|}{ Doubtful } \\
\hline & Occupation & $\begin{array}{c}\text { Glands } \\
\text { clinically } \\
\text { involved }(G) \\
\text { or not }(0)\end{array}$ & Age & Occupation & \begin{tabular}{|c|} 
Glands \\
clinically \\
involved $(G)$ \\
or not $(0)$
\end{tabular} & Age & Occupation & \begin{tabular}{|c|} 
Glands \\
clinically \\
involved (G) \\
or not $(\mathbf{0})$
\end{tabular} & Age \\
\hline 1940 & Toolmaker & G & 59 & Gas Worker* & G & 63 & - & - & - \\
\hline 1941 & - & - & - & Boatman * & G & 68 & - & - & - \\
\hline$\overline{1942}$ & Toolsetter & $\mathbf{G}$ & 53 & Chimney Sweep*+ & G & 72 & - & - & - \\
\hline 1943 & $\begin{array}{l}\text { Tube Drawer* } \\
\text { Stamper }\end{array}$ & $\begin{array}{l}\mathrm{G} \\
0\end{array}$ & $\begin{array}{l}60 \\
57\end{array}$ & \begin{tabular}{|c|} 
Carbon Rodmaker \\
Ship's Tackle \\
Painter \\
Gas Stoker
\end{tabular} & $\begin{array}{l}\mathbf{G} \\
\mathbf{0} \\
\mathbf{G}\end{array}$ & $\begin{array}{l}54 \\
62 \\
67\end{array}$ & $\begin{array}{c}\text { Sales Manager } \ddagger \\
\text { Soldier } \ddagger \\
\text { Baker }\end{array}$ & $\overline{-}$ & $\begin{array}{l}50 \\
42 \\
65\end{array}$ \\
\hline 1944 & - & - & - & $\begin{array}{c}\text { Carbon Rod } \\
\text { Worker }\end{array}$ & 0 & 56 & & & \\
\hline 1945 & - & - & - & $\begin{array}{l}\text { Tar Worker } \\
\text { Gas Stoker }\end{array}$ & $\begin{array}{l}G \\
G\end{array}$ & $\begin{array}{l}65 \\
63\end{array}$ & Labourer & $\mathbf{G}$ & 68 \\
\hline 1946 & $\begin{array}{c}\text { Toolsetter* } \\
\text { Hardener* } \\
\text { Drop Forger } \\
\text { (heat and oil) }\end{array}$ & $\begin{array}{l}0 \\
\mathbf{G} \\
0\end{array}$ & $\begin{array}{l}42 \\
31 \\
40\end{array}$ & Chimney Sweep* & G & 63 & $\begin{array}{c}\text { Labourer* }^{*} \\
\text { Power Press } \\
\text { Operator (dry) }\end{array}$ & $\begin{array}{l}G \\
0\end{array}$ & $\begin{array}{l}59 \\
62\end{array}$ \\
\hline 1947 & \begin{tabular}{|} 
Toolsetter \\
Capstan Operator \\
Degreaser \\
(paraffin)
\end{tabular} & $\begin{array}{l}\mathbf{0} \\
\mathbf{0} \\
- \\
-\end{array}$ & $\begin{array}{l}50 \\
31 \\
46\end{array}$ & & & & & & \\
\hline 1948 & $\begin{array}{c}\text { Cotton Worker } \\
20 \text { yrs. Machine } \\
\text { Operator } 12 \text { yrs. } \\
\text { Toolsetter }\end{array}$ & $\begin{array}{l}\mathrm{G} \\
\mathbf{0}\end{array}$ & $\begin{array}{l}45 \\
46\end{array}$ & \begin{tabular}{|} 
Accumulator Case \\
Moulder (pitch) \\
Pitch Worker \\
Pitch Gas Boiler \\
Worker
\end{tabular} & $\begin{array}{l}0 \\
- \\
G\end{array}$ & $\begin{array}{l}44 \\
48 \\
48\end{array}$ & \begin{tabular}{|c|} 
Railway Fitter's \\
Mate 9 yrs. Bench \\
Hand 17 yrs. \\
Blacksmith \\
Packer
\end{tabular} & $\begin{array}{l}\text { G } \\
0 \\
0\end{array}$ & $\begin{array}{l}67 \\
70 \\
63\end{array}$ \\
\hline
\end{tabular}

TOTAL FINDINGS

\begin{tabular}{|c|c|c|c|}
\hline Exposure & Patients & Deaths & Average age \\
\hline Oil & 12 & 4 & 46 \\
\hline Pitch & 13 & 4 & 58 \\
\hline Doubtful & 9 & 1 & 61 \\
\hline Grand total .. & 34 & 9 & \\
\hline
\end{tabular}

- Italics = Patient died by December, 1948.

t Cause of death apparently unrelated to carcinoma.

\$Not known if alive or dead by December, 1948.

patients having been grouped by their main occupational exposure as : ' oil', ' pitch (including tar, etc.)', 'doubtful'. This third category was necessary for those patients ( 9 in number) where the available information was not definite enough to justify inclusion in the other groups. For example, the soldier had been called up in the Manchester area and treated under Emergency Medical Service arrangements. Attempts to trace this patient failed; it would not be unreasonable to guess that he had worked in the cotton industry, but clearly, he could not be assigned to a definite category. Similarly, the railway fitter's mate had worked with oil in his early working life, but as his account of his later 
work as a bench hand showed little exposure during the later period, he was assigned on conservative grounds to the ' doubtful ' group. Of the remaining twenty-five patients, twelve were found to have been exposed to oil as against thirteen to pitch, tar or soot. These latter are well recognized carcinogens; the thirteen patients exposed to them include such typical occupations as chimney sweeps, gas workers, and men engaged with the tackle or hulls of boats. In engineering, pitch finds various specialized uses, e.g. as a binding material for making carbon rods for arc-lamps or accumulator cases for motor-cars. In this account further consideration will not be given to this category of cancer patients, except in drawing certain comparisons with the 'oil ' group.

Of the twelve patients exposed to oil, only one had worked outside the engineering industry, a man who had been a cotton worker for twenty years and transferred to engineering at the age of 33 , twelve years before reporting with scrotal cancer. The remaining eleven men had been engaged in engineering-six on machine tools exposed to cutting oils, the remaining five in the following specialized occupations : 'stamping' metal articles and exposed to oil ; ' tube drawing ' metal tubes through a heavily greased die; 'hardening' metal by quenching hot articles in oil ; 'drop forging', where the hot metal article to be hammered out is splashed over with oil to prevent its sticking to the drop hammer or to the mould; 'degreasing' plugs with trilene and paraffin.

The six workers with machine tools had all been engaged in this work for many years. A typical example may be taken in the man aged 50 who reported in 1947. As a skilled tool-setter in 1915, he was working on some of the earliest automatic machines in this country and was producing munitions. In 1919 he moved to Birmingham and continued with ' automatics', changing his firm but not his occupation in 1933. In 1940 he again changed his firm and was made a works manager, though this job still occasionally entailed contact with oil. This patient's forearms showed many flat hyperkeratoses of the types described on page 4. An intelligent observer, he nevertheless had not considered the possibility of oil as the cause of his carcinoma, particularly since his exposure had been slight during the seven years preceding the condition.

The conclusion to be drawn from the occupational histories of these patients is that skin cancer is occurring in the engineering industry, mainly in those jobs involving heavy exposure to cutting oil but also occasionally in other oily jobs. The difficulty lies in estimating the magnitude of the hazard. It is not profitable to calculate an incidence figure for the engineering industry as a whole, since this would include a majority of workers with slight or no exposure to known carcinogens. The populations of workers in definite occupations such as tool-setting can be calculated only in census years, and in view of the steady expansion of industry in Birmingham, partly by immigration, an exact incidence is again unlikely to be obtainable.

The age of each patient is also shown in Table III. The average age of the workers exposed to oil (46 years) is significantly lower than the figure ( 58 years) for those working with pitch, etc. (Difference $=12$, S.E. diff. $=3.7, P .=0.01-0.001$.) It is also lower than that previously calculated from scrotal cancer deaths or notifications of cases exposed to oil or to pitch (Henry, 1946; 1947). The explanation of this finding is conjectural, but it might be due to : (a) the carcinogen in engineering oils being more potent and hence leaving a shorter period of latency between first exposure and the development of cancer ; $(b)$ the use of mineral oil in operations leading to gross skin contamination becoming more widespread during the last twenty or thirty years.

Of these explanations $(b)$ seems more likely to be correct. It carries with it a corollary that a greater number of cases are likely to occur during the next decade than during the period under consideration. Whatever theoretical deductions are made, the fact remains that men are sometimes affected in their early 30s, although more commonly this condition is to be seen in the 5th and 6th decades of life.

In Table III, those patients, nine in number, who were known to -be dead by December 1948, are printed in italics. In two other cases information was not available, leaving thirty-two known to be alive. All nine death certificates were examined and in only one instance was the cause of death apparently unrelated to the carcinoma. In the remaining eight, the interval between the time when the condition was first reported to the hospital and the time when death occurred was $5,7,8,8,12,17,21$, and 24 months respectively. An approximate measure of the mortality due to cancer in this series may therefore be obtained by omitting from consideration all patients who reported during the last two years as well as those whose subsequent history has not been ascertained. Thus twenty-one patients remain, of whom eight are known to have died of cancer. This is equivalent to a case mortality of 38 per cent. \pm 11 per cent. A condition in which about one third of the patients die within two years is not to be regarded lightly. Table III shows whether the inguinal lymph glands were clinically enlarged or not when the patient first attended. Of the eight patients who subsequently died of cancer, seven had enlarged glands (as did a lower but appreciable proportion of the survivors). It cannot be too strongly empha- 
sized that the chances of survival in cancer of this kind depend largely upon how early the patient reports with this condition. Increasing awareness of the significance of small painless lumps on the skin and the need to seek medical advice at once must surely reduce the case mortality rate.

Wider knowledge of occupational skin cancer should also lead to improved notification. In this series, it was possible to ascertain in 19 cases whether notification had been made or not. In fact, only 4 had been notified. This failure to recognize the occupational nature of the condition greatly handicaps H.M. Inspector of Factories in his work of advising firms how best to eliminate or minimize such hazards.

\section{Biological Tests of Cutting Oil from Factory A}

Confirmation of the carcinogenic properties of an industrial chemical may be obtained by inducing tumours on experimental animals. Since the cutting oils used in industry vary considerably in composition, the choice of any one oil for biological tests presents difficulties, and a satisfactory answer can only be given by a large scale experiment. Nevertheless, a sample of the cutting oil at present in use in one of the factories was selected for biological test. The temperatures reached at the cutting edge of the tool are well above that required to produce "cracking" of the oil and theoretically might actually produce carcinogens from a previously non-carcinogenic oil. Accordingly it was considered advisable to test a sample of used oil from the sump of the machine.

Since Berenblum (personal communication) has shown that there is species difference in susceptibility to chemical carcinogens, both mice and rabbits were used as experimental animals.

\section{Biological Test on Mice}

Method.-Forty-six brown pure strain C. 57 mice were painted twice weekly with the oil ; this was applied by means of a glass rod to an area about $\frac{1}{2}$ in. by $\frac{3}{4}$ in. between the shoulder blades.

Results.-The oil caused considerable irritation to the skin of the mice, most of which had lost the hair from the area painted by the twelfth week. The skin reaction was so severe in a few of the mice that occasional paintings had to be omitted in order to allow the skin to heal. One benign highly keratinized papilloma developed on one mouse after 54 weeks' painting. No other tumours developed, although thirteen of the animals survived for 52 weeks and 50 per cent. of the animals survived for 40 weeks. This result may be interpreted to mean that the oil in question, although irritating to the skin of the mouse, was relatively non-carcinogenic to that strain.

\section{Biological Test on Rabbits}

Method. -4 albino rabbits (New Zealand whites) were used for the experiment, and the oil was applied to 6 sites on each rabbit, viz., to both ears and to shaven areas on each side of the thorax and on each flank.

Results.-The oil caused no irritation to the skin of any of the rabbits, but caused the appearance of several papillomata in the following order :

Rabbit No. 1 :

Papilloma on left flank at 24 weeks.

Papilloma on left thorax at 26 weeks; 3 more Papillomata at 30 weeks.

Papilloma on right flank at 32 weeks.

Papilloma on left ear at 34 weeks.

Rabbit No. 2 :

Papilloma on left thorax at 28 weeks ; this tumour fell off and did not re-grow.

Papilloma on right thorax at 50 weeks.

Rabbit Nos. 3 and 4.

No tumours had appeared by 52 weeks.

None of the tumours showed any sign of basal induration. The first papilloma to appear was removed for sectioning after it had been present for 8 weeks (Plate III). Histological examination confirmed that the growth was a simple pedunculated papilloma. The epithelial cells were well differentiated and producing excess keratin. The surrounding epithelium was hyperplastic but there was no evidence of malignant changes.

None of the tumours developed any signs of malignancy. The small numbers of animals used precludes an accurate quantitative estimation of the carcinogenicity of the oil to the rabbit but nevertheless the simple observation that it has the property of initiating tumour growth in that animal confirms the danger of skin exposure to cutting oils in current use.

A further point of interest in these results is the fact that the sample of oil tested was non-carcinogenic to the mouse yet produced benign tumours on the rabbit. Although isolated oil-painting experiments have been performed on rabbits, most attempts to estimate the carcinogenicity of oils are based on observations on mice only. It therefore seems desirable that in future experiments the rabbit as well as the mouse should be used, and a comparison of the tumour-producing potency for these two animals be taken into account before any oil is regarded as non-carcinogenic to man. 


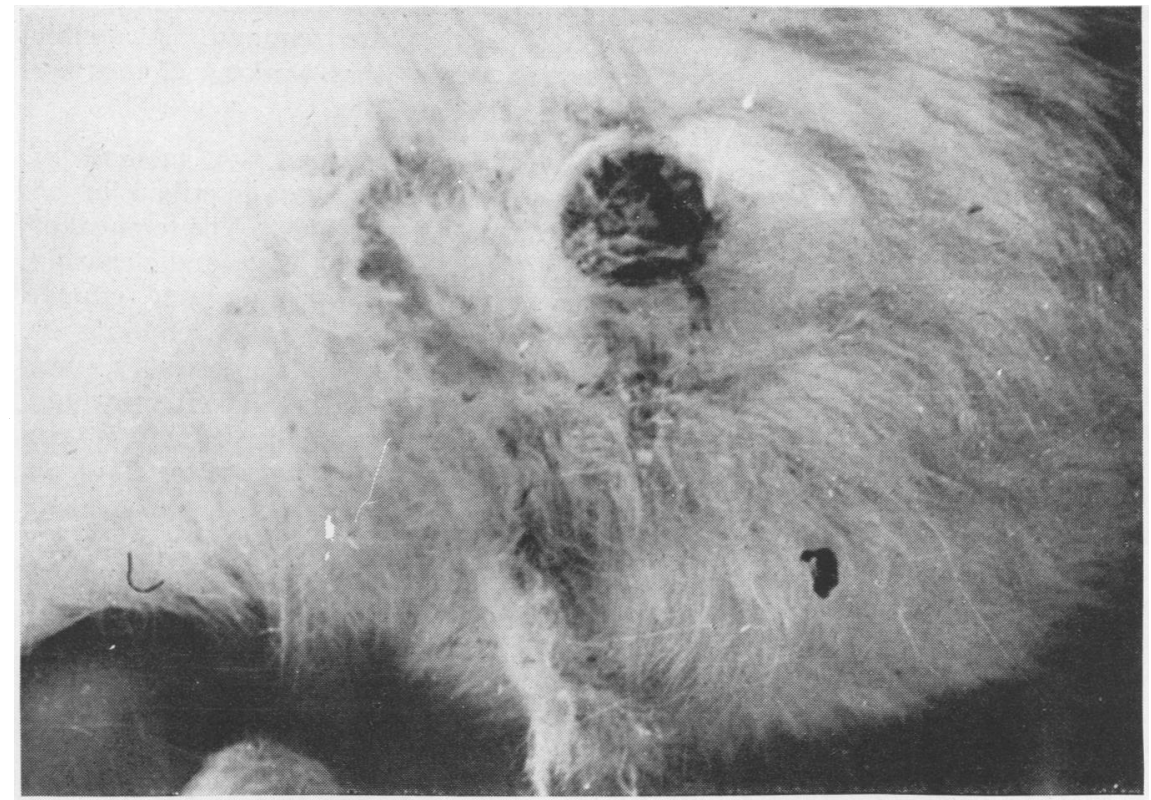

Plate III.-Papilloma on left flank of Rabbit I. Appeared after 24 weeks' painting with cutting oil. Growth is of 8 weeks' duration. skin epithelioma (cancer). The same authors also observed hyperkeratoses on the arms of workers exposed to cutting oils. The occurrence of warts on the arms of mule spinners and pitch workers, who are known to be liable to develop skin epitheliomata, suggests that a serious view should be taken of their presence. Although such hyperkeratoses do not inevitably become malignant they are to be regarded as signs of a cancer risk. The exact composition of the oils in use in the automatic shops has varied considerably during the past 15

\section{Discussion}

In this study, information has been derived from three sources. While that from any one source is not in itself conclusive, the results of all three taken together suggest that there is a definite risk of occupational cancer in the engineering industry, particularly among groups of machine operators exposed to cutting oils. It is necessary, however, to assess the significance of the findings in each of the sections of this study.

Field examination of the machine operators and toolsetters at work has demonstrated the uniformly high incidence of oil folliculitis. This in itself does not appear to constitute a grave risk to health, nor is there any suggestion that the properties of an oil which initiate folliculitis are necessarily related to its carcinogenicity. But the fact that the majority of the operators suffered from this condition shows that they are continuously exposed to a large amount of oil, and that, if the oil should be carcinogenic, they are liable to develop neoplasms at a later date.

Clear evidence has also been obtained showing that at least some cutting oils used in each machine shop inspected were capable of producing multiple hyperkeratoses after prolonged exposure. Such lesions have been observed on the arms of oil-field workers by Schwartz and others (1947) who discovered at the same examination several cases of 
If we are to avoid the considerable loss of life which would be incurred by waiting for such tumours to arise, the attempt must be made to assess the carcinogenicity of such oils by experiments on animals. The results of the preliminary biological tests described above show that at least one of the oils in use is capable of inducing benign tumours in the rabbit. But the oil tested was only a single example from the many types of oil which are at present on the market. To define the problem satisfactorily a large-scale investigation of the biological properties of various fractions from different crudes is required. This is now being carried out under the auspices of the Medical Research Council Committee on the Carcinogenicity of Mineral Oils set up in December, 1948.

But until fuller information is available it would appear desirable to urge the adoption of stricter measures to prevent skin contamination by oilespecially by cutting oils-and of any other prophylactic measures which may lessen the risks. Existing protective measures are concerned largely with preventing oil splash, protecting the person of the worker, and ensuring a high standard of cleanliness. Although failure of these measures may be due in part to the fact that the workers do not make full use of such means of protection as are available, it must be accepted that in many instances facilities are absent and that some of the protective measures recommended are inefficient. Since the production of a completely harmless cutting oil is for technical reasons unlikely to be achieved for several years, a short discussion of the possibilities of interim measures follows.

Adequate Guarding.-This would be likely to reduce the amount of skin contamination from oil splash. The guards at present in use frequently have to be removed in the course of adjusting the tool, and many workers are careless about their replacement. It is possible that the fitting of automatic spring-back devices would ensure replacement of the guard. Another criticism made is that the work cannot be clearly seen through the guards, and it is possible that local lights suitably positioned might sometimes reduce this defect. For certain processes ' insoluble cutting oils' might be replaced by watery emulsions of oil, usually known as ' suds', or even by non-petroleum mixtures. For the satisfactory evaluation of such measures, the co-operation of the doctor and engineer is necessary.

Protective Clothing.-That of the present type, made usually of leather, is heavy, hot and unwieldy. The essential garments are a long apron to cover the thighs and scrotum, and light sleeves to protect the forearms. Trials of new designs and improved materials (e.g. plastics) are required. A double locker system to ensure that working clothes are changed is also very desirable.

Cleansers and Barrier Creams.-A method of evaluating these safeguards was described in an earlier report (Cruickshank, 1948). The removal of many oils from the skin is not easy, and cleansing methods require careful selection and study. Powerful washing agents (e.g., soap-woodflour or soap-solvent mixtures) may be necessary, but provided an emollient cream is applied after washing to minimize the results of removing the natural skin fats, less harm is likely to accrue than if oil is allowed to remain in the hair follicles. 'Protective' or 'barrier' creams applied before work appear to be of little value. The demonstration of oil on the skin and the clothing by means of ultra-violet light, as described in Cruickshank's report, could be of considerable value in instructing workers in the best methods of cleansing and in periodically checking their efficiency.

Medical Inspection. - In our opinion the risks are sufficient to justify the voluntary introduction of regular medical inspection for workers exposed to cutting oils. The use of oil in industry is so widespread that it would be impracticable to inspect every person who is likely to be contaminated, but the workers exposed to cutting oils generally form well-defined groups, the supervision of which would not be difficult, at least in the larger factories. Clearly it is unnecessary to inspect those workers who have been exposed for short periods only, unless at the same time it is desired to watch for signs of oil folliculitis. This in itself would be useful as giving an index of the efficiency of the protective measures applied, but for the detection of carcinomata at an early stage, only those workers who have been exposed for more than five years need be examined.

It might be objected that the medical inspections would cause alarm among the workers, but provided that they are instituted tactfully there is no reason why this should be so. Ultimately, the success of the measures described above depends largely upon the co-operation of the worker himself. He should therefore be educated with regard to the danger of his occupation and should also be instructed how to minimize it.

Finally, reference must be made to the long-term possibility of producing non-carcinogenic oils suitable for use in the engineering industry by modern methods of oil-refining. By agitation of oil distillates in suitable solvents (e.g. liquid sulphur dioxide), highly aromatic fractions are extracted 
from petroleum distillates, leaving a mainly paraffinic ' raffinate'. 'Raffinates' have been subjected to further purification processes leading to the production of non-carcinogenic ' white oils', some suitable for use in the cotton industry. Much has yet to be learned before analogous developments can be applied economically to engineering oils, but the advance of oil refining is clearly of great importance from this biological view-point. Since many of the ' extracts' now being produced in this country are carcinogenic, as proved by animal experiment (Woodhouse and Irwin, 1949), care must be taken to ensure that these materials are not blended back into oils likely to contaminate the skins of workmen in engineering or other industries.

\section{Summary}

1. Examination of machine operators at their jobs in three factories has shown that their skins become grossly contaminated with cutting oils. As an early result 80 per cent. of the workers become afflicted with oil folliculitis.

2. In addition, those workers who have been exposed for long periods to cutting oils have on their arms multiple hyperkeratotic lesions, 60 per cent. of those who have been exposed for more than 15 years being affected.

3. A case of scrotal carcinoma in a machine operator from one of the firms has been described.

4. An investigation of the records of the United Birmingham Hospitals has revealed that during the last 10 years, 34 cases of scrotal cancer occurred. Of these, 6 occurred in machine operators and 6 in other workers exposed to oil in the engineering industry ; 13 occurred in workers exposed to tar, pitch, etc. ; the remaining 9 could not be allocated to any definite category.
5. Biological tests showed that a sample of the cutting oil in use in one of the machine shops was capable of producing benign tumours on rabbits.

6. The significance of these findings is discussed, and the existence of a hazard of skin cancer for certain workers exposed to oil in the engineering industry is indicated.

7. Measures for the protection of machine operators are reviewed.

We wish to thank the surgeons of the United Birmingham Hospitals who, through the Medical Committee chairman, Mr. B. T. Rose, F.R.C.S., gave permission to use their case notes ; Miss J. M. Levi, Follow-up officer, United Birmingham Hospitals, for access to the very complete records in her care; the industrial medical officers in various large Birmingham factories for facilitating the examination of workers; and several members of the Institute of Petroleum for technical advice.

We are also indebted to Professor A. Bradford Hill and Mr. P. Armitage of the Medical Research Council's Statistical Research Unit, London School of Hygiene and Tropical Medicine, for statistical advice.

The majority of the histological sections and reports of the scrotal cancer patients were prepared under the direction of Professor G. Haswell Wilson. Much expert advice was also given by Professor J. W. Orr, Dr. W. St. C. Symmers, and Dr. D. L. Woodhouse of the University of Birmingham.

\section{REFERENCES}

Bell, J. (1876). Edin. med. J., 22, 135.

Berenblum, I., and Schoental, R. (1943). Brit. J. exp. Path., 24, 232 Cruickshank, C. N. D. (1948). British Journal of Industrial Medicine,

Henry, S. A. (1946). " Cancer of the Scrotum in Relation to Occupation." London.

(1947). Brit. med. Bull., 4, 389.

Leitch, A. (1922). Brit. med. J., $2,1104$.

(1924). Brit. med. J., 2, 941 .

Pott, P. (1775). "Chirurgical Observations." London (quoted by Henry, S. A., 1947).

Schwartz, L., Tulipan, L., and Peck, S. M. (1947). "Occupational Diseases of the Skin." London.

Scott, A. (1922). Brit. med. J., 2, 1108 .

Southam, A. H., and Wilson, S. R. (1922). Brit. med. J., 2, 971

Twort, C. C., and Twort, J. M. (1931). J. industr. Hyg., 13, 204.

White, R. Prosser (1934). “" The Dermatergoses," (4th ed.). London. Woodhouse, D. L., and Irwin, J. O. (in press, 1949). 